\title{
Strategic analysis of the mobile services value chain in Iran's capital market and development of a mechanism to promote it
}

\author{
Bahareh Ghodoosi ${ }^{a^{*}}$, Alireza Moshkforoush ${ }^{\mathrm{b}}$, Ali Abdollahic and Mohammadesmaeil Fa- \\ daeinejad $^{c}$
}

${ }^{a}$ Department of IT Management, E-Learning Course, Tehran, Shahid Beheshti University, Iran

${ }^{b}$ Department of Management, E-Learning Course, Isfahan, Isfahan University, Iran

${ }^{c}$ Department of Management and Accounting, Tehran, Shahid Beheshti University, Iran

\section{H R O N I C L E}

Article history:

Received: July 24, 2017

Received in revised format: $\mathrm{Au}-$ gust 6,2017

Accepted: August 25, 2017

Available online:

August 25, 2017

Keywords:

Services value chain

Mobile services

Capital market

SWOT method

Environmental opportunities

\section{A B S T R A C T}

\begin{abstract}
The goal of the present study was to strategically analyze the value chain of the services based on cell phone in Iran's capital market and to present solutions for its upgrade. Nowadays, due to focusing on the customer and his needs, services are of great significance to create value for the customers. On the other hand, given the growing trend of online users, the capital market's future belongs to the online business. This research was concerned with a strategic analysis of the aforesaid services value chain. By using SWOT method, the data related to the strengths, weaknesses and threats, as well as environmental opportunities, were collected through using two questionnaires and interviews with users, specialists, and experts in technical and regulatory domains. At the end, by using descriptive statistical methods of analysis, suggestions for upgrading every part of the chain have been presented. Regarding the analyses, the weakness in communication networks and the existing infrastructure for the purpose of information transfer could be regarded as the greatest barrier to the services; also, due to the substructure problems, sometimes the users could be faced with problems such as inaccessibility to the information and inability in conducting their transactions. However, it should be noted that the companies providing these services have been successful in presenting efficient software and useful information for their users, as well as giving them deep satisfaction. Given the existing high capacity in this competitive market and the growing number of online users, it is predicted that the capital market could have the potential to be greatly prosperous and serve as an appropriate market for newcomers' activity.
\end{abstract}

\section{Introduction}

Today, electronic services are developed by expanding some concepts such as electronic business (Ebusiness) and mobile commerce (m-commerce). M-commerce is making a revolution in the business world by the innovation technology. According to researches, mobile users were 4 billion until 2010 around the world, with $90 \%$ of community in the developed countries (Gereffi \& Fernandez-Stark, 2010). Technological development in wireless communications and cellular phone and the growing number of users have led to changing the personal lifestyle and configuring business in recent years. 
According to these changes, some companies have focused on electronic services (Al-Debei et al., 2013). In recent decades, companies have tried to improve electronic devices and services, as well as reasonable prices and high quality all over the world. Smart phones are one of these improvements. Smart phones have made significant amount of values in electronic services by new technologies (Dedrick et al., 2011).

With the appearance of four-generation mobile $(4 \mathrm{G})$, data services were improved by mobile cell phone. Today, most telecommunications companies try to present variable services for achieving more benefits instead of only voice services (Lu et al., 2007). Many researches have been conducted on cell phone services with new technology and the value chain (Barnes, 2002; Camponovo \& Pigneur, 2002; Prtm, 2003; Tsalgatidou \& Pitoura, 2001). Researchers have firstly studied the marketing aspect of cell phone services (Al-Debei et al., 2013). After that, they have been concerned with designing the mobile network and improving the value of it (Tsalgatidou \& Pitoura, 2001; Tan, 2001; Varshney \& Vetter, 2002; Varshney, 2003). Using new technologies in mobile have two effects on businesses. Simplification of connections between employees, customers and suppliers is the first effect, leading to profitability and efficiency in companies. The second effect is the dynamic of business processes by changing access to data and making the chance of transaction for users (Lin et al., 2007).

Iran is one of Middle East countries with a growing number of mobile users. Many companies have started to also increase the added value to improve mobile services. Therefore, investigation of the weakness of mobile services for increasing the chain value of these services is very important. In this study, the effect of mobile services on the capital market in Iran was investigated by using a questionnaire and interviewing with users and experts (De Vellis et al., 1991; Kurttila et al., 2000). Then, according to results, some suggestions are presented to improve the value chain of the systems. Mobile services in this study mean some features through which the user can be archived by installing the marketing software on mobile. On the other hand, SWOT method is applied to analyze the value chain of services.

\section{Research methodology and design}

In this study, as the number of users was relatively big, the sampling method had be used to determine the number of interviewees. The possibility percentage of the occurring application of software was $84 \%$ in the statistical society. The confidence level in this primary study was chosen to be $95 \%$. The number of samples could be calculated by the following equation:

$$
n=\frac{z_{\alpha / 2}^{2} P(1-P)}{d^{2}}
$$

,where $z \alpha / 2$ is the alpha level's z-standard score for normal distribution (1.96), $P$ is possibility percentage (84) and $d$ is the confidence level, which is equal to 0.05. According to Eq (1), the number of samples was calculated to be 206 . For reducing the possible errors, 25 percent of all samples were added to samples and increased to 257. After the distribution of the questionnaire among people, because of the incompleteness of some answers, they were rejected. Finally, the number of samples for analysis became 240 people.

The questions of the questionnaire included five sections covering the aim of this study. The components of each section were recognized according to the analysis by SWOT method and the questions were drafted. The Likert scale was used to answer the questions. In this scale, the agreement of responder with each question was determined based on the scale, from 1 (very low) to 5 (very much). The number of questions for each section is shown in Table 1. 
Table 1

Classification of questions in six sections

\begin{tabular}{ccc}
\hline Number of rows & Sections & Number of questions \\
\hline 1 & Users & $1-3$ \\
2 & Services & $4-20$ \\
3 & Technology & $21-26$ \\
4 & Communication networks & $27-32$ \\
5 & Legislative & $33-37$ \\
6 & Competitive market & $38-40$ \\
\hline
\end{tabular}

A conceptual model for this study is shown in Fig. 1.

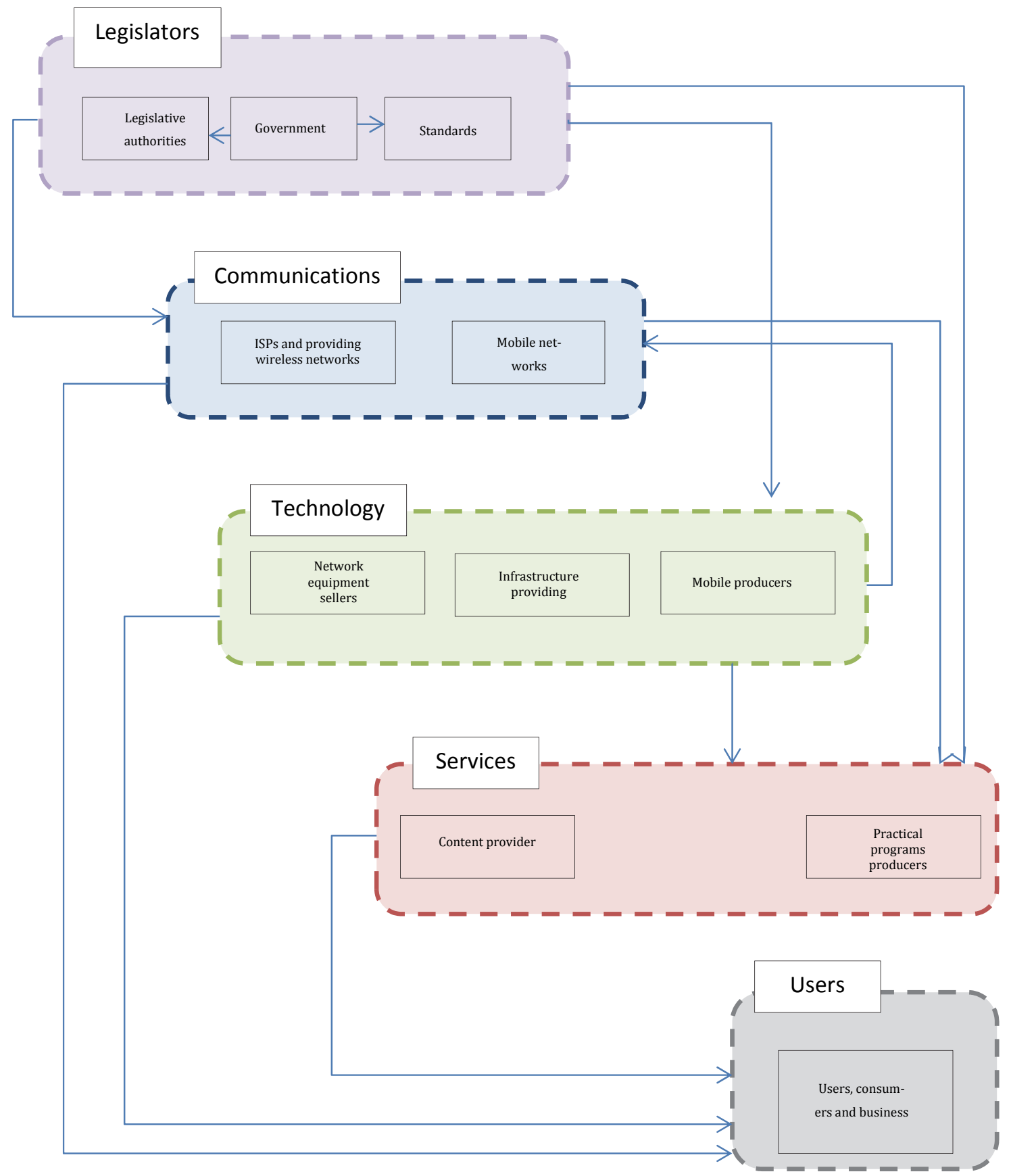

Fig.1. A conceptual model for investigating value chain of mobile services in Iran's capital market 
To validate the questionnaire, Cronbach's alpha criterion was used. This criterion could show if other samples were chosen for answering to questions, would result to be the same as before. If the number of questions is shown by $K$ and each question by $\mathrm{Y}_{\mathrm{i}} \mathrm{Xi}=\mathrm{Y}_{1}+\mathrm{Y}_{2}+\ldots \ldots \mathrm{Y}_{\mathrm{i}}$ Cronbach's alpha can be calculated by the following equation (De Vellis \& Dancer, 1991):

$$
\alpha=\frac{K}{K-1}\left(1-\frac{\sum_{i=1}^{K} \sigma_{Y_{i}}^{2}}{\sigma_{X}^{2}}\right)
$$

, where $\sigma_{Y_{i}}$ and $\sigma_{x}$ are standard divisions of each question and whole questions, respectively. For more information and points, experts were interviewed. The obtained data were analyzed by the SWOT method or other statistical analyses. The statistical tests used in this study included the binomial test and the Friedman variance analysis test. For pros and cons, the binomial test was used. The binomial test included two groups with questions in the Likert scale; first group was less or equal to 3 and the second one was more than 3. Fig. 2 shows the schematic of the research program.

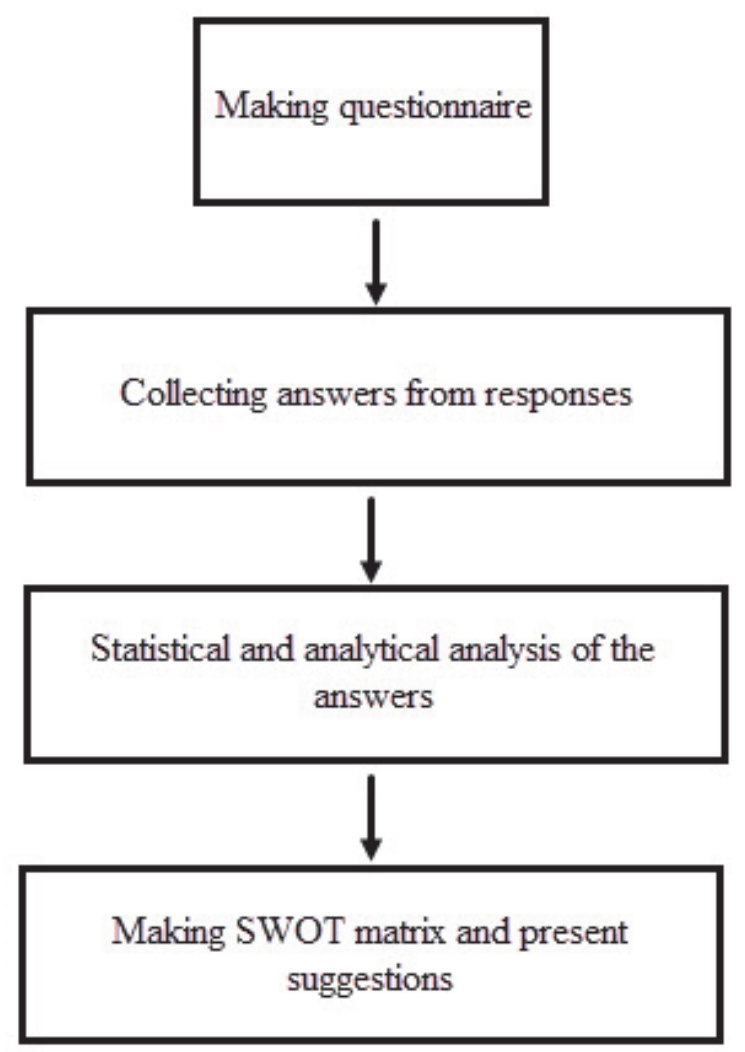

\section{Results and discussion}

Fig. 2. The schematic of the research program

According to Table 1, questions were divided to six sections including users, services, technology, communication networks, legislative and competitive market. Table 2 shows the average and standard division of each section.

\section{Table 2}

Statistical indicators for each component

\begin{tabular}{cccc}
\hline Component & Sample numbers & Average & Standard division \\
\hline Users & 240 & 3.62 & 0.56 \\
Services & 240 & 3.66 & 0.43 \\
Technology & 240 & 3.08 & 0.4 \\
Communication networks & 240 & 2.75 & 0.76 \\
Legislative & 240 & 3.3 & 0.6 \\
Competitive market & 240 & 3.22 & 0.53 \\
\hline
\end{tabular}


According to Table 2, services were the strongest component and communication networks could be regarded as the weakest one in the value chain. Details of the analysis of each section are shown in the following section.

\subsection{Analyzing of components for the users section}

The results for the first component are shown in Table 3. According to Table 3, the significance level for the first component was less than 0.05 . On the other hand, the frequency of the second group was more than that of the first group. Therefore, this component could be considered as an opportunity.

Opportunity: Using stock services software by mobile could lead to improving the users' efficiency in their jobs.

The significance level for the second and third components was more than 0.05 . Moreover, these two components were in the middle level and could be considered as threat, but the amount of this threat was not too much.

Threat: Users have enough knowledge to work with the software.

Table 3

Statistical indicators for users' components

\begin{tabular}{|c|c|c|c|c|c|c|}
\hline $\begin{array}{l}\text { No of compo- } \\
\text { nents }\end{array}$ & Component & Group & Levels & Numbers & $\begin{array}{c}\text { Percentage of } \\
\text { observation }\end{array}$ & Validity \\
\hline \multirow{2}{*}{1} & \multirow{2}{*}{$\begin{array}{l}\text { Using stock mobile } \\
\text { software leads to } \\
\text { improving effi- } \\
\text { ciency }\end{array}$} & First group & $\begin{array}{c}\text { Less or } \\
\text { equal to } 3\end{array}$ & 44 & 18 & \multirow{2}{*}{0.000} \\
\hline & & Second group & More than 3 & 196 & 82 & \\
\hline \multirow[t]{2}{*}{2} & \multirow{2}{*}{$\begin{array}{l}\text { Users have enough } \\
\text { knowledge to work } \\
\text { with software }\end{array}$} & First group & $\begin{array}{c}\text { Less or } \\
\text { equal to } 3\end{array}$ & 124 & 52 & \multirow[t]{2}{*}{0.784} \\
\hline & & Second group & More than 3 & 116 & 48 & \\
\hline \multirow{2}{*}{3} & \multirow{2}{*}{$\begin{array}{l}\text { Users know safety } \\
\text { tips for protecting } \\
\text { their privacy }\end{array}$} & First group & $\begin{array}{c}\text { Less or } \\
\text { equal to } 3\end{array}$ & 124 & 52 & \multirow[t]{2}{*}{0.784} \\
\hline & & Second group & More than 3 & 116 & 48 & \\
\hline
\end{tabular}

As can be seen in Table 3, the majority of responders emphasized on the positive effects of using stock software on mobile, believing that this capital market software could improve the efficiency of user's works. But, for user's knowledge and their awareness of safety tips, percentages in the first and the second groups were almost the same.

Given the increase in the number of online users in the stock market, it could be inferred that users would want to do online deals without brokers. In future, brokers could play the role of consultants in the capital market. But some users did not have enough knowledge about capital market rules and the safety tips for protecting from privacy information. Therefore, the companies that produced software could play an important role in informing users by inperson or virtual training.

\subsection{Analysis of components for the services section}

The results for the services section are shown in Table 4. For the components 10 and 14, the significance level was less than 0.05 and the frequency of the first group was more than that of the second one. Therefore, they belonged to the weak point. The weak point means that software was not able to be installed on the variable mobile with variable operating systems. On the other side, Strengths mean that software could have a user-friendly application, considering the privacy of users; so it could be useful information, as well as updating the information. 
The significance level for the components $9,11,12,13$ and 15 was more than 0.05 and it was in the middle level. Therefore, they could not be taken as strengths. On the other hand, for the components 4, $5,6,7,8,16,17,18,19$ and 20 , the significance level was less than 0.05 . The frequency of the second group (more than 3 ) was more than that of the first group (less or equal to 3 ) for these components. So, they included the strengths.

\section{Table 4}

Statistical indicators for services components

\begin{tabular}{|c|c|c|c|c|c|c|}
\hline $\begin{array}{l}\text { No of com- } \\
\text { ponents }\end{array}$ & Component & Group & Levels & Numbers & $\begin{array}{c}\text { Percentage of } \\
\text { observation }\end{array}$ & Validity \\
\hline \multirow{2}{*}{4} & \multirow{2}{*}{ the ease of use with software } & First group & Less or equal to 3 & 48 & 20 & \multirow{2}{*}{0.000} \\
\hline & & Second group & More than 3 & 192 & 80 & \\
\hline \multirow{2}{*}{5} & \multirow{2}{*}{ the quality of being software user-friendly } & First group & Less or equal to 3 & 60 & 25 & \multirow{2}{*}{0.000} \\
\hline & & Second group & More than 3 & 180 & 75 & \\
\hline \multirow{2}{*}{6} & \multirow{2}{*}{ The ease of learning software } & First group & Less or equal to 3 & 68 & 28 & \multirow{2}{*}{0.000} \\
\hline & & Second group & More than 3 & 172 & 72 & \\
\hline \multirow{2}{*}{7} & \multirow{2}{*}{ Harmonizing services with user needs } & First group & Less or equal to 3 & 92 & 38 & \multirow{2}{*}{0.013} \\
\hline & & Second group & More than 3 & 148 & 62 & \\
\hline \multirow{2}{*}{8} & \multirow{2}{*}{$\begin{array}{l}\text { High capacity for protecting privacy and } \\
\text { user's information }\end{array}$} & First group & Less or equal to 3 & 64 & 27 & \multirow[t]{2}{*}{0.000} \\
\hline & & Second group & More than 3 & 176 & 73 & \\
\hline \multirow{2}{*}{9} & \multirow{2}{*}{ Low cost to buy the software } & First group & Less or equal to 3 & 116 & 48 & \multirow{2}{*}{0.784} \\
\hline & & Second group & More than 3 & 124 & 52 & \\
\hline \multirow{2}{*}{10} & \multirow{2}{*}{$\begin{array}{l}\text { High speed of software to provide infor- } \\
\text { mation and services }\end{array}$} & First group & Less or equal to 3 & 160 & 67 & \multirow{2}{*}{0.000} \\
\hline & & Second group & More than 3 & 80 & 33 & \\
\hline \multirow{2}{*}{11} & \multirow{2}{*}{ Novelty in the provision of services } & First group & Less or equal to 3 & 108 & 45 & \multirow{2}{*}{0.315} \\
\hline & & Second group & More than 3 & 132 & 55 & \\
\hline \multirow{2}{*}{12} & \multirow{2}{*}{ Good support service for software } & First group & Less or equal to 3 & 108 & 45 & \multirow{2}{*}{0.315} \\
\hline & & Second group & More than 3 & 132 & 55 & \\
\hline \multirow{2}{*}{13} & Ability to merge and integrate web, mobile & First group & Less or equal to 3 & 120 & 50 & 1 \\
\hline & and computer for the users' comfort & Second group & More than 3 & 120 & 50 & 1 \\
\hline & High ability to install software in different & First group & Less or equal to 3 & 192 & 80 & \\
\hline 14 & mobiles with different operating systems & Second group & More than 3 & 48 & 20 & 0.000 \\
\hline & Availability of information for using soft- & First group & Less or equal to 3 & 100 & 42 & \\
\hline 15 & ware & Second group & More than 3 & 140 & 58 & 0.082 \\
\hline 16 & Provision of useful output information for & First group & Less or equal to 3 & 68 & 28 & 0000 \\
\hline 16 & the user & Second group & More than 3 & 172 & 72 & 0.000 \\
\hline 17 & Correlation of the provided information with & First group & Less or equal to 3 & 72 & 30 & \\
\hline 17 & the user's need & Second group & More than 3 & 168 & 70 & 0.000 \\
\hline & & First group & Less or equal to 3 & 36 & 15 & \\
\hline 18 & Update of the provided information & Second group & More than 3 & 204 & 85 & 0.000 \\
\hline 19 & High precision and trust in the provided in- & First group & Less or equal to 3 & 88 & 37 & \\
\hline 19 & formation & Second group & More than 3 & 152 & 63 & 0.004 \\
\hline 20 & Comprehensiveness of the provided infor- & First group & Less or equal to 3 & 92 & 38 & 0.013 \\
\hline 20 & mation & Second group & More than 3 & 148 & 62 & 0.013 \\
\hline
\end{tabular}

According to the pervious table, the ease of working with software and the high capability for protecting privacy and user's information were the most desirable ones and more than 70 percent of respondents agreed with these components. On the other side, the speed of software in the provided services had the most dissatisfaction in the answers. After that, the cost of buying software and the integrity between web and mobile were the two components causing the most satisfaction.

The services section was divided to "software producers" and "content producers". In the "software producers" section, software has a good design, creating trust in the user for protecting privacy. But the capability to integrate web, mobile and computer, and the ability to install software on different mobiles with different operating systems can be considered weak in supporting the services section. The speed of the available software is the main weak point of them. The strength of this section is the ease of learning and using the available software. Therefore, companies working in this filed can make a comparative market by supplying various software with better and innovative supported services. 


\subsection{Analysis of components for the technology section}

According to the results for the technology section, as shown in Table 5, the significance level for the components 21,23 and 26 was less than 0.05 , but for the question 23 , the frequency of the second group was more than that for the first group. Therefore, this component could be an opportunity. Opportunity is the ease of work with smart phones. For the components 21 and 26, the frequency of the first group (Less or equal to 3 ) is less than that of the second group (more than 3 ). Therefore, these components could be taken as threats. Threat is inadequate for the variations of mobile models and brands and weaknesses in the infrastructures for communication between software producers companies and stock exchange database.

\section{Table 5}

Statistical indicators for technology components

\begin{tabular}{|c|c|c|c|c|c|c|}
\hline No of components & Component & Group & Levels & Numbers & $\begin{array}{c}\text { Percentage of } \\
\text { observation }\end{array}$ & Validity \\
\hline \multirow{2}{*}{21} & \multirow{2}{*}{$\begin{array}{l}\text { Accessibility of the convenient } \\
\text { mobile for installing software }\end{array}$} & First group & Less or equal to 3 & 164 & 68 & \multirow{2}{*}{0.000} \\
\hline & & Second group & More than 3 & 76 & 32 & \\
\hline \multirow{2}{*}{22} & \multirow{2}{*}{$\begin{array}{l}\text { Low cost of buying the conven- } \\
\text { ient mobile }\end{array}$} & First group & Less or equal to 3 & 140 & 58 & \multirow{2}{*}{0.082} \\
\hline & & Second group & More than 3 & 100 & 42 & \\
\hline \multirow{2}{*}{23} & \multirow{2}{*}{$\begin{array}{l}\text { Ease of work with the convenient } \\
\text { mobile }\end{array}$} & First group & Less or equal to 3 & 80 & 33 & \multirow{2}{*}{0.000} \\
\hline & & Second group & More than 3 & 160 & 67 & \\
\hline \multirow{2}{*}{24} & \multirow{2}{*}{$\begin{array}{c}\text { Good support services for mo- } \\
\text { biles }\end{array}$} & First group & Less or equal to 3 & 124 & 82 & \multirow{2}{*}{0.784} \\
\hline & & Second group & More than 3 & 116 & 48 & \\
\hline \multirow{2}{*}{25} & \multirow{2}{*}{$\begin{array}{l}\text { Low cost of necessary equipment } \\
\text { for software producers }\end{array}$} & First group & Less or equal to 3 & 132 & 55 & \multirow{2}{*}{0.315} \\
\hline & & Second group & More than 3 & 108 & 45 & \\
\hline \multirow[b]{2}{*}{26} & \multirow{2}{*}{$\begin{array}{l}\text { Existence of the convenient in- } \\
\text { frastructure for communication } \\
\text { between software producers }\end{array}$} & First group & Less or equal to 3 & 152 & 63 & \multirow[b]{2}{*}{0.004} \\
\hline & & Second group & More than 3 & 88 & 37 & \\
\hline
\end{tabular}

According to Table 5, the highest point belonged to the ease of using mobile. But, the most dissatisfaction was for the absence of the convenient mobile and the necessary infrastructure for communication between software producers companies and the stock exchange database.

According to the results of this section and experts' comments, preparing and installing the equipment can be too expensive for companies. On the other hand, absence of enough knowledge for using these equipment is one of the weak points. It is the reason for problems for newcomers. Therefore, installing the convenient infrastructures and supervision can be an important subject that supervisory authority should consider. The strength of this section is good user's knowledge for working with smart phone.

\subsection{Analysis of components for the communication networks section}

The results for the communication networks section are shown in Table 6. According to the results for the components $27,28,29,31$ and 32 , the significance level was less than 0.05 . For the components $27,28,29,31$ and 32, the frequency for the first group (less or equal to 3) was more than that for the second group (more than 3 ), so it could be regarded as a threat. In this section, threat means the inappropriate coverage of mobile in all parts of the city, inaccessibility to internet by mobile in all parts of the city, absence of competition between different mobile operators for providing cheaper and better services, absence of convenient supported services by operators and the high mobile internet cost. The component number 30 was in the middle level; therefore it was not a threat. As shown in Table 6, this section caused the most dissatisfaction among the users. Except the component number 30, more than 60 percent of respondents were dissatisfied with other components.

Communication networks could be regarded as the most inefficient section, causing a lot of problems for the user. Absence of coverage by mobile networks in all parts of the city was one of problems. On the other hand, the cost of mobile internet was high, making a competition between mobile operators. It seemed that increasing the competition between mobile operators could improve mobile services. 
Table 6

Statistical indicators for communication networks components

\begin{tabular}{|c|c|c|c|c|c|c|}
\hline No of components & Component & Group & Levels & Numbers & $\begin{array}{l}\text { Percentage of ob- } \\
\text { servation }\end{array}$ & Validity \\
\hline \multirow[t]{2}{*}{27} & \multirow{2}{*}{$\begin{array}{l}\text { Convenient coverage of mo- } \\
\text { bile network in city }\end{array}$} & First group & Less or equal to 3 & 156 & 65 & \multirow[t]{2}{*}{0.001} \\
\hline & & Second group & More than 3 & 84 & 35 & \\
\hline \multirow[t]{2}{*}{28} & \multirow{2}{*}{$\begin{array}{l}\text { Access to internet by mobile } \\
\text { in all parts of the city }\end{array}$} & First group & Less or equal to 3 & 184 & 77 & \multirow[t]{2}{*}{0.000} \\
\hline & & Second group & More than 3 & 56 & 23 & \\
\hline \multirow[t]{2}{*}{29} & \multirow{2}{*}{$\begin{array}{l}\text { The low cost of using inter- } \\
\text { net by mobile }\end{array}$} & First group & Less or equal to 3 & 144 & 60 & \multirow[t]{2}{*}{0.035} \\
\hline & & Second group & More than 3 & 96 & 40 & \\
\hline \multirow{2}{*}{30} & \multirow{2}{*}{$\begin{array}{l}\text { Installing a new generation } \\
\text { of mobile network for ac- } \\
\text { cess to high speed internet }\end{array}$} & First group & Less or equal to 3 & 116 & 48 & \multirow{2}{*}{0.784} \\
\hline & & Second group & More than 3 & 124 & 52 & \\
\hline \multirow{2}{*}{31} & \multirow{2}{*}{$\begin{array}{l}\text { High competition between } \\
\text { different operators for } \\
\text { providing cheaper and better }\end{array}$} & First group & Less or equal to 3 & 156 & 65 & \multirow{2}{*}{0.001} \\
\hline & & Second group & More than 3 & 84 & 35 & \\
\hline \multirow[t]{2}{*}{32} & \multirow{2}{*}{$\begin{array}{l}\text { Good support services of } \\
\text { mobile networks }\end{array}$} & First group & Less or equal to 3 & 204 & 85 & \multirow[t]{2}{*}{0.000} \\
\hline & & Second group & More than 3 & 36 & 15 & \\
\hline
\end{tabular}

\subsection{Analysis of components for legislative section}

Table 7 shows the results for legislative section. The significance level for 33 and 37 components was less than 0.05 . The frequency of the first group (less or equal to 3) was more than that of the second group (more than 3); so, these could be taken as the threat. Threats can consist of the absence of certain standards in all fields and lack of support by government in providing convenient facilities. For the questions 34,35 and 36 , the significant level was more than 0.05 . They were in the middle level; therefore, they could not be taken as an extreme opportunity.

Table 7

Statistical indicators for legislative components

\begin{tabular}{|c|c|c|c|c|c|c|}
\hline $\begin{array}{l}\text { No of com- } \\
\text { ponents }\end{array}$ & Component & Group & Levels & Numbers & $\begin{array}{c}\text { Percentage of ob- } \\
\text { servation }\end{array}$ & Validity \\
\hline \multirow{2}{*}{33} & Existence of certain standards in all & First group & Less or equal to 3 & 160 & 67 & \multirow{2}{*}{0.000} \\
\hline & steps & Second group & More than 3 & 80 & 33 & \\
\hline \multirow{2}{*}{34} & Existence of rules for providing & First group & Less or equal to 3 & 120 & 50 & \multirow{2}{*}{1} \\
\hline & stock services by mobile & Second group & More than 3 & 120 & 50 & \\
\hline \multirow[b]{2}{*}{35} & Application of useful rules to pro- & First group & Less or equal to 3 & 112 & 47 & \multirow[b]{2}{*}{0.523} \\
\hline & $\begin{array}{l}\text { tect privacy and the confidential } \\
\text { information of users }\end{array}$ & Second group & More than 3 & 128 & 53 & \\
\hline \multirow{2}{*}{36} & Supervision of the stock of soft- & First group & Less or equal to 3 & 120 & 50 & \multirow{2}{*}{1} \\
\hline & ware producers & Second group & More than 3 & 120 & 50 & \\
\hline \multirow[b]{2}{*}{37} & Government support from this field & First group & Less or equal to 3 & 164 & 68 & \multirow[b]{2}{*}{0.000} \\
\hline & $\begin{array}{c}\text { by providing the convenient facili- } \\
\text { ties }\end{array}$ & Second group & More than 3 & 76 & 32 & \\
\hline
\end{tabular}

According to Table 7, the lowest point belonged to providing convenient facilities by government. For the rules and quality of supervising the stock for software producers, the satisfaction was on the middle level. The stock exchange with comprehensive supervision on software producer companies could create good satisfaction in the users. But the absence of collaboration and convenient integration between supervisory authorities and software producer companies could cause some problem for the users.

The responders point to weak supported by government in this field. Given the capital market in Iran and the potential of this filed, government could make convenient infrastructure and provide various facilities to help boom the market and the user could take part in this field.

\subsection{Analysis of components for competitive market section}

The significance level for the component 39 was less than 0.05 and the frequency for the first group was more than that for the second group. Therefore, it could be considered as an opportunity. Opportunity could be defined as low competition between companies providing software. For thequestions 38 
and 40, the significance level was more than 0.05 and the frequency of these components was in the middle level. So these components could not take as an extreme opportunity. The results for the competitive market section are shown in Table 8.

\section{Table 8}

Statistical indicators for the competitive market components

\begin{tabular}{|c|c|c|c|c|c|c|}
\hline Component No & Component & Group & Levels & Numbers & $\begin{array}{l}\text { Percentage of ob- } \\
\text { servation }\end{array}$ & Validity \\
\hline \multirow[t]{2}{*}{38} & \multirow{2}{*}{$\begin{array}{l}\text { The ease for newcomers to enter } \\
\text { to this field }\end{array}$} & First group & Less or equal & 120 & 50 & \multirow[t]{2}{*}{1} \\
\hline & & Second group & More than 3 & 120 & 50 & \\
\hline \multirow[t]{2}{*}{39} & \multirow{2}{*}{$\begin{array}{l}\text { High competition between soft- } \\
\text { ware producing companies }\end{array}$} & First group & Less or equal & 168 & 70 & \multirow[t]{2}{*}{0.000} \\
\hline & & Second group & More than 3 & 72 & 30 & \\
\hline \multirow{2}{*}{40} & \multirow{2}{*}{$\begin{array}{l}\text { Existence of original segments for } \\
\text { presenting services based on mo- } \\
\text { bile in the capital market }\end{array}$} & First group & Less or equal & 100 & 42 & \multirow{2}{*}{0.082} \\
\hline & & Second group & More than 3 & 140 & 58 & \\
\hline
\end{tabular}

According to Table 8, the competition between companies is not as a threat and in this field, there are some original segments in which newcomers can work. The competition in this market in low, and few companies work on this filed. According to responder's answers and experts' comments, entering for newcomers is easy, but competition with big companies is too hard. Therefore, newcomers, by using nobility in productions and entering the original filed, can make a new market.

Friedman test was carried out on all components to determine the priority of opportunities, threats, strengths and weak points. The Friedman test is a non-parametric statistical test used to detect differences in treatments across multiple test attempts.

\subsection{SWOT analysis}

After that, SWOT analysis was conducted on all sections to present convenient suggestions for each section. SWOT analysis is a structured approach to evaluate an organization with respect to its internal and external environments. By identifying factors in a SWOT matrix, action plans can be developed to augment strengths, eliminate or minimize weaknesses, exploit opportunities and identify threats (Kurttila et al., 2000). In SWOT analysis, the external environment and the internal resources of the organization can be investigated and summarized in key subjects. By interacting between these components, four strategies (WT, ST, OT and SO) can be defined. SO strategy is the operation of the external opportunity by internal strength. Improving internal weak points by considering the existing opportunities is the WO strategy. ST strategy is decreasing the effects of threats from the external environment by using organization strength. Defensive mode can be seen in companies using the WT strategy. The aim of the WT strategy in this study is reduction of internal weak points and prevention of external environment threats. On the other hand, 15 experts reviewed the provided strategies and their suggestions were investigated for final solutions. The matrix of SWOT analysis is shown in Table 9.

\section{Table 9}

SWOT matrix

\begin{tabular}{ccc}
\hline Always white & Strengths $(\mathrm{S})$ & Weak points $(\mathrm{W})$ \\
\hline Opportunities & SO strategy & WO strategy \\
Threats & ST strategy & WT strategy \\
\hline
\end{tabular}

According to Table 9, the SWOT matrix for suggestions in different sections can be defined as shown Table 10. 


\section{Table 10}

\section{Final SWOT matrix}

$\begin{array}{cc}\text { Weak points (W): } & \text { Strengths (S): } \\ \begin{array}{cc}\text { - Low speed in presenting services - Disa- } \\ \text { bility in installing software on different }\end{array} & \text { - Providing updated and exact infor- } \\ \text { mobiles with different operating systems } & \text { mation for the users } \\ & \text { - Protecting the privacy and information } \\ \text { of users in software } \\ \text { - Good design of software (to ease learn- } \\ \text { ing software by users) } \\ \text { - Proportioning the presented services } \\ \text { from software and the users' need } \\ \text { - The low cost to buy software } \\ \text { - Novelty in the presented services } \\ \text { - Convenient supported services for soft- } \\ \text { ware }\end{array}$

\section{SO strategy:}

- Designing systems for the supervision of users and customer's relationship management (CRM)

- Classification of the way software services presented to users in proportion to service-level agreement (SLA)

- Designing software systems according to different platforms

- Improving network and communication infrastructures in companies

\section{WT strategy:}

- Review of chain value models based on mobile in Iran's capital market with the supervision of legislators

- Using the outsourcing method for better and cheaper infrastructure

- Integration of systems based on mobile
- Presence of innovation systems and services based on mobile, such as using genetic algorithm and automatic order based on mobile

- Designing decision support (DSS) systems based on mobile with other companies' package software

- A culture improving the use of mobile services in the capital market

\section{ST strategy: Threats (T):}

- The use of the capability of mobile for teaching users (providing educational software)

- Cooperation with companies and operators that present services as strategic cooperation

- Presenting integrated solution according to software, hardware and network infrastructure

- Making various communication networks to provide interface software for communication with databases market this field
Opportunities $(\mathrm{O})$ :

- Optimistic view of users to make use of software to improve efficiency

- Existing pristine segments in the presence of mobile services in the capital

- Ability of users to use new smart phones - Installing new generation mobile net-

work for accessing the high speed internet

- Effectiveness of laws to protect privacy and information of users

- Absence of convenient supported services for different mobile operators

- Absence of access to internet in different parts of the city

- Absence of coverage by mobile network in different parts of the city

- Absence of effective competition be-

tween different operators to provide better and cheaper services

- Inefficient support by government from

- Limiting the convenient mobile to use the software

- Absence of the convenient standard in all fields (from infrastructures to software design)

- Absence of the convenient infrastructure for communication between software producers and database

- High cost of using internet by mobile

- High cost of buying convenient mobile on which software can be installed at

- High cost of providing equipment for software producers

- Low knowledge of users for using the software

Therefore, solutions according to priority can be summarized in Table 11 . 
Table 11

Prioritize of suggested solutions

\begin{tabular}{cl}
\hline \multicolumn{1}{c}{ Priority } & \multicolumn{1}{c}{ Solution } \\
\hline 1 & $\begin{array}{l}\text { Classification of the way software services presented to users in proportion to service-level } \\
\text { agreement (SLA) } \\
\text { Integration of systems based on mobile with other companies' package software }\end{array}$ \\
\hline 2 & $\begin{array}{l}\text { The use of the capability of mobile for teaching users (providing educational software) } \\
\text { Review of chain value models based on mobile in Iran's capital market with the supervision of } \\
\text { legislators }\end{array}$ \\
& $\begin{array}{l}\text { A culture improving the use of mobile services in the capital market } \\
\text { Presence of innovation systems and services based on mobile, such as using genetic algorithm } \\
\text { and automatic order based on mobile }\end{array}$ \\
& $\begin{array}{l}\text { Cooperation with companies and operators that present services as strategic cooperation } \\
\text { Presenting integrated solution according to software, hardware and network infrastructure } \\
\text { Making various communication networks to provide interface software for communication with } \\
\text { databases }\end{array}$ \\
& Designing software systems according to different platforms \\
\hline & $\begin{array}{l}\text { Designing decision support (DSS) systems based on mobile } \\
\text { Providing interface software for communication with databases }\end{array}$ \\
\hline & Improving network and communication infrastructures in companies \\
& Designing systems for the supervision of users and customer's relationship management (CRM) \\
\hline
\end{tabular}

\section{Conclusion}

This study focused on the mobile services value chain in Iran's capital market. Therefore, the effect of mobile services on the value chain in Iran's capital market was investigated by preparing the questionnaire and interviewing with the experts.

Based on the results obtained in this study, communication networks can be considered as the weakest section for mobile services in the capital market. Therefore, cooperation between the operators could improve communication networks, making a comparative market leading to be better services. Positive section refers to the "users", which contained the most points. The users believed that using software for doing online deal could lead to increasing efficiency in the capital stock. But user training is an important subject that software producers should be taken in to account. In the technology section, the absence of the convenient infrastructure could be a main problem. So, installing new equipment to make the convenient infrastructure and considering users for providing the appropriate mobile could be suggested for this section. Stock and exchange organization could also make use of a good supervision on software producer companies. But government supports could lead to booming capital market and increasing the value chain in this filed. The competition between software producer companies is too low. On the other hand, few companies have been able to work up in this filed until now. Because of the existence of original segments in the capital market software, newcomer companies can work up in original filed, thereby making a good comparative marketing.

\section{References}

Barnes, S. J. (2002). The mobile commerce value chain: analysis and future developments. International Journal of Information Management, 22(2), 91-108.

Camponovo, G., \& Pigneur, Y. (2002, July). Analyzing the actor game in m-business. In Proc. First International Conference on Mobile Business, Athens.

Al-Debei, M. M., Al-Lozi, E., \& Fitzgerald, G. (2013). Engineering innovative mobile data services: Developing a model for value network analysis and design. Business Process Management Journal, 19(2), 336-363. 
Dedrick, J., Kraemer, K. L., \& Linden, G. (2011). The distribution of value in the mobile phone supply chain. Telecommunications Policy, 35(6), 505-521.

Gereffi, G., \& Fernandez-Stark, K. (2010). The offshore services value chain: developing countries and the crisis. Durham: Center on Globalization Governance and Competitiveness - Duke University. Commisioned by CORFO.

Kurttila, M., Pesonen, M., Kangas, J., \& Kajanus, M. (2000). Utilizing the analytic hierarchy process (AHP) in SWOT analysis - a hybrid method and its application to a forest-certification case. Forest Policy and Economics, 1(1), 41-52.

Lin, C. H., Shih, H. Y., \& Sher, P. J. (2007). Integrating technology readiness into technology acceptance: The TRAM model. Psychology \& Marketing, 24(7), 641-657.

Lu, Y., Dong, Y., \& Wang, B. (2007). The mobile business value chain in China: a case study. International Journal of Electronic Business, 5(5), 460-477.

Prtm, U. (2003). The ecology of mobile commerce: charting a course for success using value chain analysis. Mobile Commerce: Technology, Theory, and Applications, 122.

Tsalgatidou, A., \& Pitoura, E. (2001). Business models and transactions in mobile electronic commerce: requirements and properties. Computer Networks, 37(2), 221-236.

Tan, K. C. (2001). A framework of supply chain management literature. European Journal of Purchasing \& Supply Management, 7(1), 39-48.

Varshney, U. (2003). Mobile and wireless information systems: applications, networks, and research problems. Communications of the Association for Information Systems, 12(1), 11.

Varshney, U., \& Vetter, R. (2002). Mobile commerce: framework, applications and networking support. Mobile networks and Applications, 7(3), 185-198.

De Vellis, R. F., \& Dancer, L. S. (1991). Scale development: theory and applications. Journal of Educational Measurement, 31(1), 79-82.

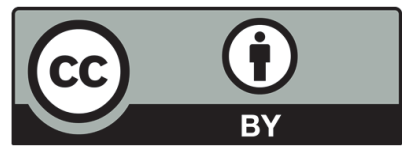

(C) 2017 by the authors; licensee Growing Science, Canada. This is an open access article distributed under the terms and conditions of the Creative Commons Attribution (CC-BY) license (http://creativecommons.org/licenses/by/4.0/). 